\title{
Analisis Vegetasi Gulma di lahan Tanaman Jagung (Zea mays L.)
}

Analysis Vegetation of weeds in land corn

Fitria*1 $^{*}$ Efrida $^{1}$, Fitra Syawal Harahap ${ }^{2}$

1.Program Studi Agroteknologi Fakultas Pertanian Universitas Muhammadiyah Sumatera Utara Medan 20238

2.Progam Studi Agroteknologi Sekolah Tinggi Ilmu Pertanian (STIPER) Universitas Labuhan Batu 21418 Sumatera Utara

*Corresponding Author : fitria@umsu.ac.id

\section{ABSTRACT}

Research analysis vegetation a weed in three districts in North Sumatra that had undertaken in march 2019 with instrument square measure of $50 \times 50 \mathrm{~cm}$ the research by counting value SDR( Summed Dominance Ratio) indicate that of a corn plant district Simalungun shows the SDR dominant weed Ageratum Conyzoides (41.27\%), Deli Serdang weed Ageratum conicoides (27.38\%) and Karo weed Imperata Cylindrica ( $32.16 \%$ ).The research results showed that there were differences in the type weed on the corn plant for district simalungun and Deli Serdang indicates the type of weed that same (Broad leaves) and Kabupaten karo showed weed( Grasses).

Key words :analysis, Vegetation weed, corn

\begin{abstract}
ABSTRAK
Penelitian Analisis vegetasi gulma di tiga kabupaten di sumatera utara yang telah dilaksanakan pada bulan Maret 2019 dengan meggunakan Alat square ukuran 50 x $50 \mathrm{~cm}$ dari hasil penelitian dengan menghitung nilai SDR (Summed Dominance Ratio) menunjukkan bahwa tanaman jagung Kabupaten Simalungun Menunjukkan nilai SDR yang dominan gulma Ageratum conyzoides (61.17\%), Deli Serdang gulma Cyperus esculentus $(30,15 \%)$ dan Karo jenis gulma Imperata cylindrica $(27,66 \%)$. Hasil Penelitian menunjukkan bahwa ada perbedaan jenis gulma pada tanaman jagung untuk kabupaten Simalungun dan deli serdang menunjukkan jenis gulma yang sama berdaun lebar (Broad leaves) sedangkan kabupaten karo menunjukkan gulma alangalang (Grasses).
\end{abstract}

Kata Kunci : analisis,vegetasi gulma, jagung

\section{PENDAHULUAN}

Jagung merupakan tanaman serealia yang yang bernilai strategis dan ekonomi serta mempunyai peluang untuk dikembangkan karena kedudukannya sebagai sumber utama karbohidrat dan protein setelah beras juga sebagai sumber pakan. Upaya peningkatan produksi jagung masih menghadapi berbagai masalah sehingga produksi jagung dalam negeri belum mampu mencukupi kebutuhan nasional (Soerjandono, 2008).Tanaman jagung berasal dari benua Amerika yang 
tumbuh sekitar 4.500 tahun yang lalu di pegunungan Andes, Amerika Selatan. Tanaman jagung dibawa ke Indonesia oleh orang Portugis dan Spanyol sekitar 400 tahun yang lalu. Pusat pertanaman jagung di benua Asia terdapat di Cina, Filipina, India, Indonesia (Rukmana dan Yudirachman, 2007).

Menurut Badan Pusat Statistik (2015) Produksi jagung di propinsi Sumatera Utara dengan luas panen 245.773 ha dengan produksi 1.519.407 ton/ ha dan produktivitas rata-rata $62.33 \mathrm{kwintal} / \mathrm{ha}$. Sedangkan Kabupaten Deli Serdang adalah dengan luas panen 16.001 ha dengan produksi 74.324 ton/ha dan produktivitas rata-rata $46.45 \mathrm{kwintal} / \mathrm{ha}$. Produktivitas kabupaten tergolong rendah jika dibandingkan dengan kabupaten lainnya seperti Kabupaten Karo adalah dengan luas panen 83.931 ha dengan produksi 577.924 ton/ha dan produktivitas rata-rata 68.86 kwintal/ha.

Gulma merupakan tumbuhan yang mengganggu atau merugikan kepentingan manusia sehingga manusia berusaha untuk mengendalikannya (Sembodo, 2010). Jenis gulma meliputi gulma rumput (grasses), gulma golongan tekian (seedges) dan gulma golongan berdaun lebar (broad leaves). Beberapa jenis gulma yang hidup di pertanaman jagung Abutilon theophrasti, Agropyron repens, Amaranthus sp., Ambrosia sp. , Avene fatua , Brassica sp., Chenopodium album, Cynodon dactilon, Cyperus esculentus, Cyperus rotundus, Digitaria sanguinalis, Echinochloacrus galli, Imperata cylindrical. Di Sumatera utara banyak ditemukan pertanaman jagung salah satunya adalah Deli serdang, karo dan simalungun. Berdasarkan hasil survei lapangan vegetasi gulma yang hidup dipertanaman jagung tersebut adalah golongan rumput, golongan tekian, golongan daun lebar atau golongan pakis- pakisan akan tetapi sampai saat ini belum ada penelitian yang menginformasikan mengenai gulma jagung tersebut.

Berdasarkan dari penjelasan dan uraian di atas, maka penulis tertarik melakukan penelitian dengan judul "Analisis vegetasi gulma tanaman jagung pada tiga kabupaten di sumatera utara".

\section{BAHAN DAN METODE}

Penelitian dilaksanakan pada tiga kabupaten Deli Serdang, Karo dan SimalungunProvinsi Sumatera Utara dengan ketinggian tempat berbeda beda dengan curah hujan rata-rata $1500 \mathrm{~mm}$ per tahun dan topografi datar. Tanaman jagung yang ditanam petani dilaksanakan dari mulai bulan oktober sampai dengan selesai.

Bahan yang digunakan dalam penelitian ini adalah tanaman jagung di lahan kering Alat yang digunakan dalam penelitian ini adalah cangkul, Alat Square ukuran 50 x $50 \mathrm{~cm}$, buku deskripsi gulma atau herbarium, kantong plastik, alat tulis, kantong kertas oven timbangan, label, lem kertas, kamera, serta alat-alat lain yang mendukung percobaan ini. Penelitian ini dengan Analisis vegetasi gulma dengan menghitung nilai SDR pada setiap petak percobaan. Nilai SDR didapatkan dengan menghitung setiap jumlah spesies gulma yang terdapat pada petak contoh. Nilai SDR diperoleh dengan menggunakan rumus yang dikemukankan oleh Kusmana (1997) sebagai berikut :

SDR $=($ Kerapatan Nisbi + Frekuensi Nisbi $)$ : 2, Kerapatan Mutlak suatu jenis = jumlah individu tiap jenis, Kerapatan Nisbi suatu jenis $=($ kerapatan Mutlak jenis itu : Jumlah Kerapatan semua jenis) x 100\%. Frekuensi Mutlak suatu Jenis $=($ Jumlah Petak contoh berisi jenis itu : Jumlah semua Petak contoh yang di ambil) x 100\%, Frekuensi Nisbi suatu jenis $=($ Frekuensi Mutlak jenis itu : 
jumlah Frekuensi Mutlak semua jenis ) $\mathrm{x}$ $100 \%$

Pelaksanaan penelitian dengan cara dilemparkan alat square method sebanyak banyaknya 5 kali pada lahan kering untuk membuat petak contoh dengan ukuran $50 \mathrm{x}$ $50 \mathrm{~cm}$. Diambil gulma yang tumbuh pada petak contoh tersebut. Dimasukan kedalam kantong plastik gulma yang diperoleh dan diberi nama sesuai dengan lahan dan nomor petak contohnya dengan menggunakan label. Diidentifikasi jenis gulma yang ada dengan menggunakan buku deskripsi gulma berdasarkan cirri morfologinya yang sebelumnya telah dicuci. Ditulis nama spesies dan jumlah dari masing-masing gulma yang diidentifikasi dan dimasukan ke dalam kantong kertas. Setelah diidentifikasi, gulma yang ada dalam kantong kertas dimasukan kedalam oven sampai kering konstan. Dilakukan pengovenan selama dua hari. Ditimbang masing-masing jenis gulma yang telah dioven. Dihitung kerapatan, frekuensi, dan dominasi masing-masing jenis gulma.

\section{HASIL DAN PEMBAHASAN}

\section{Simalungun}

Hasil Analisis vegetasi gulma pada tanaman jagung untuk Kabupaten simalungun menunjukkan bahwa gulma berdaun lebar lebih dominan Ageratum conyzoides dengan nilai SDR $(61,17 \%)$ diikuti Imperata cylindrica (50,57\%), Cleome rutidosperma (35,42\%) dibandingkan gulma lainnya seperti gulma berdaun sempit hal ini di karena Gulma Berdaun Lebar (Broad Leaves) tumbuh pada akhir budidaya. Pada umumnya merupakan tumbuhan berkeping dua, meskipun ada juga yang berkeping satu. Gulma berdaun lebar memiliki ciri-ciri bentuk daun melebar dan tanaman tumbuh tegak atau menjalar. Berbagai macam gulma dari Dicotyledoneae termasuk dalam kelompok ini. Kompetisi terhadap tanaman utama berupa kompetisi cahaya. Daun dibentuk pada meristem pucuk dan sangat sensitif terhadap kemikalia. Terdapat stomata pada daun terutama pada permukaan bawah, lebih banyak dijumpai. Terdapat tunas-tunas padanodusa, serta titik tumbuh terletak di cabang.

Tabel 1. Nama spesies gulma di Simalungun dan kerapatannya

\begin{tabular}{llccccc}
\hline \multirow{2}{*}{ Kabupaten } & \multicolumn{1}{c}{ Nama Spesies } & KM & FM & KR(\%) & FR(\%) & SDR (\%) \\
& Amaranthus spinosus & 1 & 1 & 3.03 & 12.50 & 7.77 \\
\multirow{3}{*}{ Simalungun } & Mimosa pudica & 1 & 1 & 3.03 & 12.50 & 7.77 \\
& Oxalis corniculata & 9 & 2 & 27.27 & 25.00 & 26.14 \\
& Cyperus rotundus & 1 & 1 & 3.03 & 12.50 & 7.77 \\
& Imperata cylindrica & 21 & 3 & 63.64 & 37.50 & 50.57 \\
& Ageratum conyzoides & 28 & 3 & 84.85 & 37.50 & 61.17 \\
& Phyllanthus niruri L & 1 & 1 & 3.03 & 12.50 & 7.77 \\
& Euphorbia hirta L & 1 & 1 & 3.03 & 12.50 & 7.77 \\
& Passiflora foetida & 14 & 2 & 42.42 & 25.00 & 33.71 \\
& Cleome rutidosperma & 11 & 3 & 33.33 & 37.50 & 35.42 \\
\cline { 2 - 7 } & Total & $\mathbf{3 3}$ & $\mathbf{8}$ & $\mathbf{1 0 0}$ & $\mathbf{1 0 0}$ & $\mathbf{1 0 0}$ \\
\hline
\end{tabular}




\section{Deli Serdang}

Hasil Analisis Hasil Analisis vegetasi gulma pada tanaman jagung untuk Kabupaten Deli Serdang menunjukkan bahwa gulma berdaun lebar dominan Ageratum conicoides dengan nilai SDR $27,38 \%$ diikuti Cyperus esculentus (24,05\%), Ipomea cordatotriloba $(21,83 \%)$ dibandingkan gulma lainnya hal ini di karena Gulma Berdaun Lebar (Broad Leaves) tumbuh pada akhir budidaya hal ini tidak jauh berbeda dengan gulma di Simalungun.

\section{Karo}

Hasil Analisis Hasil Analisis vegetasi gulma pada tanaman jagung untuk Kabupaten Karo berbeda dengan gulma pada kabupaten Simalungun dan Deli Sedang hal ini menunjukkan bahwa gulma berdaun sempit lebih dominan Imperata cylindrica dengan nilai SDR 27,66 \% diikuti Borreria laevis $(22,92 \%)$, Synedrella nodiflora $(19,81 \%)$ hal ini dikarenakan lahan yang digunakan merupakan lahan bukaan baru bekas hutan dan penyiangan gulma belum semua terangkat ke permukaan kemungkinan masih ada tersisa biji gulma di dalam tanah sehingga gulma tersebut tumbuh kembali dan menggangu tanaman jagung Kabupaten Karo berbeda dengan Simalungun dan Deli Serdang. Gulma Berdaun Sempit/Rerumputan (Grasses)Gulma berdaun sempit memiliki ciri khas sebagai berikut: daun menyerupai pita, batang tanaman beruas-ruas, tanaman tumbuh tegak atau menjalar, hidup semusim, atau tahunan dan memiliki pelepah serta semusim, atau tahunan dan memiliki pelepah serta helaian daun. Golongan gulma rurumputankebanyakan berasal dari famili gramineae (poaceae). Batangnya disebut culms.

Tabel 2. Nama Species Gulma dan sebarannya di Kabupaten Deli Serdang

\begin{tabular}{llccccc}
\hline \multirow{2}{*}{ Kabupaten } & Nama Spesies & KM & FM & KR(\%) & FR(\%) & SDR (\%) \\
\hline \multirow{5}{*}{ Deli Serdang } & $\begin{array}{l}\text { Ipomea } \\
\text { cordatotriloba }\end{array}$ & 10 & 3 & 22.22 & 21.43 & 21.83 \\
$\begin{array}{l}\text { Ageratum } \\
\text { conicoides }\end{array}$ & 15 & 3 & 33.33 & 21.43 & 27.38 \\
& Oxalis barrelieri L. & 3 & 2 & 6.67 & 14.29 & 10.48 \\
\cline { 2 - 7 } & $\begin{array}{l}\text { Phylanthus } \\
\text { urinaria(meniran) }\end{array}$ & 1 & 1 & 2.22 & 7.14 & 4.68 \\
& $\begin{array}{l}\text { Cyperus esculentus } \\
\text { Gelagah anjing }\end{array}$ & 12 & 3 & 26.67 & 21.43 & 24.05 \\
\cline { 2 - 7 } & Total & $\mathbf{4 5}$ & $\mathbf{1 4}$ & $\mathbf{1 0 0}$ & $\mathbf{1 0 0}$ & $\mathbf{1 0 0}$ \\
\hline
\end{tabular}


Tabel 2. Nama Species Gulma dan sebarannya di Kabupaten Deli Serdang

\begin{tabular}{|c|c|}
\hline Kabupaten & Nama Spesies \\
\hline \multirow[t]{2}{*}{ Karo } & $\begin{array}{l}\text { Synedrella nodiflora } \\
\text { Imperata cylindrica } \\
\text { Gelagah } \\
\text { Borreria laevis } \\
\text { Mimosa pudica } \\
\text { Amarantus spinosus }\end{array}$ \\
\hline & Total \\
\hline \multicolumn{2}{|c|}{ SIMPULAN } \\
\hline \multicolumn{2}{|c|}{$\begin{array}{l}\text { Kabupaten Simalungun dan Deli } \\
\text { Serdang spesies gulma yang dominan adalah } \\
\text { gulma berdaun lebar, hal ini karena tanah } \\
\text { tempat tumbuh tanaman jagung sudah sering } \\
\text { berulang kali ditanamani dan gulma ini } \\
\text { muncul pada akhir budidaya, sedangkan } \\
\text { Kabupaten Karo spesies gulma alang-alang } \\
\text { hal ini karena, tanah bekas hutan belum } \\
\text { bersih saat penyiangan sehingga masih ada } \\
\text { biji gulma yang tertinggal di dalam tanah, } \\
\text { sehingga tumbuh kembali. Simalungun dan } \\
\text { Deli Serdang gulma yang dominan (SDR) } \\
\text { adalah Ageratum conicoides sedangkan } \\
\text { kabupaten Karo Imperata cylindrica }\end{array}$} \\
\hline
\end{tabular}

\section{DAFTAR PUSTAKA}

Ashton, F. M. dan F. J. Monaco, 2012, Weed Science: Principle and Practice John Willey and Sons. Inc N. Y. pp. 419.

Astri. A., 2012. Teknik Pengendalian Gulma Pada Tanaman Jagung. BPTP Kalimantan Tengah. Badan Litbang Pertanian. Kementrian Pertanian.

Badan Pusat Statistik Propinsi Sumatera Utara, (2015). Luas Panen, Produksi dan Rata-Rata Produksi Jagung Menurut Kabupaten/Kota.

Clay, A.S. and I. Aquilar. 1998; Moenandir, 2010). Weed Seedbanks end Corn Growth Following Continous Corn or Alfalfa. Agron. J. 90:813-818.

Djojosumatro, P., 2008. Panduan Lengkap Pestisida dan Aplikasinya. PT. Agromedia Pustaka. Jakarta Selatan.

Fadhly dkk., 2007. Pengaruh Cara Penyiangan Lahan dan Pengendalian Gulma Terhadap pertumbuhan Dan Hasil Jagung Pada Tanah Bertekstur Berat. Seminar Mingguan Balai Penelitian Tanaman Serealia, Maros, 18 Juni 2004, p:14.

Farnham, D.E., G.O. Benson, and R.B. Pearce. 2003. Corn Perspective and Culture, p. 1-33. In P.J. White and L.A. Johnson (Eds.). Corn Chemistry and Technology Second Edition. American Association of Cereal Chemists, Inc. Minnesota.

Gem, C. 1996. Kamus Saku Biologi. Erlangga. Jakarta.

Habibah, E.Z. 2005. Uji Daya Hasil Lima Genotipe Jagung Manis pada Dua Lokasi Kabupaten Bogor. Skripsi. Departemen Budidaya Pertanian, 
Institut Pertanian Bogor. Bogor. 45 hal.

Mueller-Dombois, D. dan H. Ellenberg. 1974. Aims And Methods Of Vegetation Ecology. New York.

Odum, E. P. 1993. Dasar-Dasar Ekologi: Edisi Ke Tiga. Gajah Mada University Press. 694 hlm. Yogyakarta.

Riahi, E. and H.S. Ramaswamy. 2003. Structure And Composition Of Cereal Grains And Legumes, p. 1-16. In A. Chakroverty, A.S. Mujumdar, G.S.V. Raghavan, H.S. Ramaswamy (Eds.). Handbook of Postharvest Technology Cereals, Fruits, Vegetables, Tea, and Spices. Marcel Dekker Inc. New York.

Rukmana, R dan Yudirachman, H. 2007. Jagung Budi Daya, Pasca Panen, dan Penganeka ragaman Pangan. Penerbit Aneka Ilmu.Semarang

Sembodo, D. 2010. Gulma dan Pengelolaannya. Yogyakarta : Graha Ilmu.
Soerjandono, N. B. 2008. Teknik Produksi Jagung Anjuran di Lokasi Peimatani Kabupaten Sumenep. Buletin Teknik Pertanian.

Subekti, N. A., Syafruddin, R. Efendi, dan S. Sunarti. 2007. Morfologi Tanaman dan Fase Pertumbuhan Jagung, hal 1628. Pusat Penelitian dan Pengembangan Tanaman Pangan, Departemen Pertanian. Jakarta.

Subekti,et.al. 2007. Morfologi dan Fase Pertumbuhan Jagung, Dalam Jagung. Pusat Penelitian dan Pengembangan Tanaman Pangan. Jakarta. hal 16-28

Surasana et al. 1990. Pengantar Ekologi Tumbuhan. Bandung: ITB.

Yernelis.1995. Gulma dan Teknik Pengendaliannya. Rajawali Pers, Jakarta 